\title{
litating Community, Enabling Democracy: New Roles for Local Government Managers
}

Public Administration Review

November/December 1999

\author{
John Nalbandian \\ Department of Public Administration \\ University of Kansas
}

June 1998 


\section{Facilitating Community, Enabling Democracy: New Roles for Local Government Managers}

Dennis Hays, administrator of the Unified Government of Wyandotte County/Kansas City, Kansas, found himself in an unfamiliar role. In the presence of the Governor, the Mayor, and other dignitaries, Hays was asked to take the lead in a press conference announcing that the International Speedway Corporation had begun negotiating with the Unified Government as a partner in the construction of a NASCAR racetrack. His highly visible role in the project was being recognized and future expectations cast.

Kansas City, Kansas, once a manufacturing stronghold in northeast Kansas, is a city searching for lost pride. Hays, analytical and compassionate, and educated to believe that the role of the manager is to work backstage, found himself leading a project that would have significant effect on the sense of community in this city.

This research, based on data gathered from open-ended survey questions, correspondence, and in-depth panel discussions, also utilizes earlier findings for a "then and now" examination of the contemporary roles, responsibilities, and values of city managers. City managers are seen as community builders and enablers of democracy. With those goals, they have become skilled at facilitative leadership and building partnerships and consensus. Also, they have become more aware that legitimacy of the city manager role demands more than a legal foundation in council-manager 
government, the manager's adherence to the value of efficiency, and making recommendations based on "the greatest good for the greatest number over the long run." In today's political environment of diverse and conflicting interests, managers must anticipate and attend to claims for equity, representation, and individual rights if they are to succeed as partner to the elected officials and citizens they serve and as leader of the professional staff they supervise.

\section{Method}

Ten years ago Ray Davis and I set out to explore the meaning of professionalism in local government through a series of interviews with city and county managers. Around the same time, George Frederickson invited a group of city management professionals to Lawrence to discuss "ideal and practice" in council-manager government. Each project resulted in publications commenting on the meaning of professionalism in local government (Frederickson, 1989; Nalbandian 1989, 1990, 1991).

In order to make a 10 year comparison, I contacted the professionals who had participated in the original projects and who were still connected with local government, asking them to review their 10 year old interview or essay. To that number I added city managers who had written "state of the profession" articles in Public Management over the past five years. In addition, I contacted ICMA winners of the Mark E. Keane award for Excellence in Local Government, and, I invited participation of a few more 
local government professionals who, over the years, I have found particularly drawn to this topic.

I asked these 26 professionals to answer the following three questions in writing:

- What are the most significant changes that have occurred in local government in the last 10 years?

- What changes have occurred in relationships between the governing body and chief administrative officer and in the politics of local government?

- What parts of the manager's job have remained the most stable over the 10 years? And which parts have changed the most?

I collected the responses, and convened two panel discussions at the 1997 annual ICMA meeting in Vancouver with six of the participants. I added their transcribed remarks to the original comments, and then reviewed everything I had received along with the few articles that appeared in Public Management magazine. I selected passages exemplifying what appeared to me as emergent themes and conveyed those remarks to all of the participating managers, asking for additional comments. With those in hand, I settled on the themes that best describe the meaning of professionalism in local government as it has evolved over the past 10 years. Seeking additional feedback, I sent a draft of the resulting manuscript to the managers who had provided comments I quoted. Where possible, I have used the words of local 
government professionals extensively to illustrate the changes that have occurred, as experienced by these public servants.

\section{The Past}

In my earlier review of professionalism in local government I concluded that city management had transformed itself over several decades in three fundamental ways. It had "moved from an orthodox view of a dichotomy between politics and administration to the sharing of functions between elected and appointed officials; from political neutrality and formal accountability to political sensitivity and responsiveness to community values themselves; and from efficiency as the core value to efficiency, representation, individual rights, and social equity as a complex array of values anchoring professionalism" (Nalbandian, 1991, p. 103). The first change represented an evolution in roles, the second a broader statement of professional responsibility, and the third set out to capture the contemporary value base of city management.

Those familiar with professionalism in local government will see that to a large extent many recent changes have reinforced these transformations. During the past 10 years, the following changes stand out:

- $\quad$ Community building has become part of the city management professional's responsibility

- Managers are expected to facilitate participation and representation, and to develop partnerships 
- There is less adherence to council manager government as the "one best form"

- The manager's internal administrative role has become more process oriented

\section{What's New}

\section{Community Building}

Historical reviews of city management reveal a continuing search for the meaning of professionalism (Stillman, 1974). As social, economic, political, and technological trends create new contexts, the roles, responsibilities, and values of practicing professionals change. In my earlier project, I tried to define professionalism in local government as grounded in a broader array of community values than had been posited traditionally. But, what I failed to articulate was the search for a sense of community as a way to conceptualize a context for contemporary professional work.

Since the original research in the late-1980s, many voices have spoken to the themes of building community, civil society, and civic infrastructure as partial solutions to the growing distance between citizens and governing institutions. In his study of Italian regional governments Putnam (1993) found that the presence of social capital, identified with the concepts of a rich network of local associations, active engagement in community affairs, egalitarian patterns of politics, and trust and lawfulness, positively affected 
economic development and the performance of governing institutions. Rice and Sumberg's (1997) research, focusing on the United States, reinforces Putnam's conclusions. In another academic vein, many (Box, 1998; Lappe and DuBois, 1994; Mathews, 1994) have argued that reconnecting citizens to government requires government oriented towards citizen involvement rather than control by professional elites. Frederickson (1997A) poses a complementary challenge, asserting that local government professionals are in a unique position to enhance civil society and help build social capital if "the community paradigm were to become part of the bureaucrat's understanding of how the city ought to be" (p. 31).

None of the city managers in this study actually used the term community building to describe their work. But the term seems apropos to how they describe what they do, especially when considered in the following theoretical way. From a public official's perspective, community building essentially involves building political capacity--the capacity to make collective decisions amidst diverse and conflicting interests. A crucial component of this capacity is developing a sense of responsibility among citizens to participate in and obligate themselves to collective decisions. The obligation stems 1) from an understanding that certain tasks require collective and public action rather than private, individual decisions, and 2) from an expectation that the agents of governing institutions will respect the values of representation, individual rights, and social equity so that 
individual citizens do not suffer from capricious or arbitrary collective decisions (Tussman, 1960). In short, getting problems solved collectively while respecting the values of representation, individual rights, and social equity builds a sense of obligation to the collective good and constitutes one way of looking at community building.

With renewed interest nationwide in the paradigm of community, one can argue that in the future the legitimacy of professional administrators in local government will be grounded in the tasks of community building and enabling democracy--in getting things done collectively, while building a sense of inclusion. Contemporary comments by Karma Ruder, Director of the Neighborhood Planning Office in Seattle, and Eric Anderson, City Manager in Des Moines, illustrate this point.

Describing the professional's role in local government, Ruder (August $12,1997)$ writes, "Who is doing the work that makes people respect their government and become committed to making life in their communities better? The crucial issue is how local governments stay legitimate in the eyes of those they serve."

Anderson (August 26, 1997) writes,

I am increasingly convinced that we are accountable for more than the quality of our management. We are also accountable for how well we have performed in the governance of our 
communities. Our jobs are to assure a fundamentally productive combination of the two [politics and administration] in the daily life of local governments. We need to be more specific about the responsibility we carry for governance as well as service delivery.

He (Anderson, September 17, 1997) develops this notion further with these thoughts:

We have a strong responsibility to make sure that we provide not only information to our governing bodies, but to support the processes of governance that support the representative nature of the city council. I'm not talking about getting involved in electoral politics, but in things like public hearings, discussion, and deliberation; training people in the organization to anticipate and foster participation; and building structures of participation that will be seen as legitimate. I don't think we have done a very good job on the governance side of our responsibilities.

In a panel discussion at the ICMA Conference in Vancouver, British Columbia, Norm King (September 16, 1997), the Executive Director of San 
Bernardino Associated Governments in Southern California, and former ICMA President, said, "There is a remarkable degree of value consistency in what we all represent. And I heard it today, especially in terms of the focus on the engagement of citizens in creating a more just society."

He went on to talk about how he would advance that goal. "The primary goal of government, and especially local government, is to create conditions that insure, foster, or encourage responsibility. This means creating responsibility in the people who work for us; in our customers; and in our citizens."

Community building is a theme that expresses our understanding of how the city management profession is evolving, but this work does not come without a challenge. On the one hand community building as a context for grounding professional practice seems a clarion call from many voices (Etzioni, 1995; Glendon, 1991; Mathews, 1994; Selznick, 1992). In Howard Gardner's (1995) terms, it is a good story; it conveys a noble message Americans today want to hear even as they strive to enhance the quality of their private lives. The concept of community building is attractive as a base for the practice of city management because with it comes an understanding that both politics and administration are crucial, often inseparable, and must work in the kind of partnership that most local government professionals value rather than the adversarial relationship with their governing body in which they occasionally find themselves. 
The challenges to the call for community building are the long-term social, political, and economic trends that have fragmented society and in insufficient transferable knowledge of how exactly to build and maintain a sense of community. In addition, for city managers, as issues become broadly regional or narrowly oriented around neighborhoods, municipal boundaries become less relevant demarcations of community (Church, November 27, 1997; O'Neill, Jr., October 29, 1997). But perhaps the most formidable challenge to the community paradigm is a compelling counter-story. This is the respected and enduring tale of self-reliance and self-interest, adherence to market-based values, and skepticism regarding the value of government (Fowler, 1991). As local government professionals come to realize that their work connects them to the processes of governing through community building, they also come to acknowledge that those advocating market values pose a vigorous challenge.

Local government professionals regard this challenge in contrasting ways. For some, it appears simply another political change to be accommodated. Examples include comments from William Buchanan (October 17, 1997), Manager in urban Sedgwick County, Kansas, which includes Wichita. "Today, I believe elected officials are clearly more diverse and have a higher sense of public service than witnessed recently. They certainly come to the task from a much more 'Reaganesque' approach than 10 years ago. Government is to be used only as a last resort, power is to be 
shared, and partners are to be used to solve problems. This kind of reluctant use of power requires a different style of leadership [for the manager]."

David Watkins (July 21, 1997), City Administrator in Lenexa, Kansas, a conservative suburb of Kansas City, writes, "I think the movement toward customer service as a value has helped our image. In Lenexa, we work hard trying to create an image that we are tough but fair problem solvers who value the benefits of business and residents to the community and who want to work with you, not against you."

Jan Perkins (July 13, 1997), City Manger in Freemont, California, adds, "The city manager needs to lead the organization in changing and adapting to community expectations--becoming entrepreneurial, customer focused, citizen involved--in order for the city council to have faith and confidence in the direction the city manager is taking the organization."

Buchanan, Watkins, and Perkins help us understand that local government professionals must ground their practice in the political context of their work. In contemporary America, they are working in various partnerships to build a sense of community in places where "community" and "individual" compete vigorously in determining public purposes and the role of government.

Facilitative Role of the Manager

Participation and Representation 
Local government professionals from California to Virginia comment that the greatest change they have seen over the past 10 years is the amount and character of participation expected in public policymaking and problem solving. The theme is not new; it has been emphasized in city management literature since the $1960 \mathrm{~s}$, and it is completely consistent with the community building/enabling democracy theme (Rutter, 1980). What seems different now is its pervasiveness and its transforming quality. Bill Buchanan (October 17, 1997) writes, "We are required to share power. How we manage special needs and the fragmentation of centralized power seem to me to be the parts that have changed the most. How we define and then use and manage democracy to provide service will control the styles and types of skills municipal managers will need to be successful." And Charles Church (November 27, 1997), City Manager in Lynchburg, Virginia writes, "Reform should allow citizens to be fully engaged in the processes of local governance. I anticipate that neighborhood councils will increasingly take over many of the responsibilities of city councils and administrators for setting priorities and evaluating service delivery." The participation and representation theme is seen in working with diverse council members; through community problem solving processes; and in a variety of partnerships.

\section{Diversity}

The diversity on councils is seen with more representation of race and gender, with more special interest candidates, and with more anti- 
government council members. Potentially, each represents a different way of viewing the role of government, the council's work, and relationships with citizens and professional staff (Bledsoe, 1993). The differences would seem to be greater than those seen in the past, at least from a local government professional's perspective.

These differences produce contrasting consequences. On the one hand, when effectively blended they increase the problem solving capacity of the governing body. On the other hand, the differences can easily consume a council and render it ineffective (Mahtesian, 1997). The diversity on councils can be more extensive than the differences confronted in familiar daily work groups. In the absence of hierarchy, task specialization, systematic and credible feedback, and specific task definition, it is no wonder that council's flounder and the local government professionals seeking leadership and policy guidance from them become frustrated.

When effectively managed, this diversity seems to make a positive difference in communities. David Mora (December 5, 1997), city manager in Salinas, California, writes,

The local government manager is responsible for advocating comprehensive participation and representation in governance issues. Part of the frustration today is the diversity and overwhelming nature of service demands from parts of the 
community that in the past either were not represented or were taken for granted by both elected and appointed local government officials. The new generation of local elected officials, representing a significantly diverse variety of interests, is demanding legitimate and comprehensive responses from management.

He continues by suggesting that the way to deal with diversity on the council is by reflecting that diversity among staff. He says that he himself had to learn to be more inclusive, to accept the diversity of the community. He and Eric Anderson argue that as city managers trying to relate to councils more representative of the community, it is easier to work with a staff that reflects an array of values and anticipates the council's expectations because then staff can tacitly understand them.

The connection between diversity and problem solving marks a significant departure from diversity as affirmative action. What was seen in the past, sometimes cynically as diversity for the sake of political correctness or, more positively as moral virtue, is now seen as diversity for the sake of problem solving. What was once seen as the "right thing to do" is now seen as a prudent way to staff an organization for problem solving, especially in environments in which problem solving among diverse interests and political legitimacy go hand in hand. 


\section{Problem Solving}

The relationship between politics, participation, problem solving, and legitimacy marks a departure from previous conceptions of the connection between citizens and local government officials. John Thomas (1986) notes that local governments began a few decades ago to invite a relationship based on the negotiation of interests. He contrasted this to the historic relationship based on "petition" or "redress." Current comments from local government professionals suggest that this association may be moving again, this time from "adversarial negotiations" toward "interest-based policymaking."

Karma Ruder (December 15, 1997): "Citizens more and more want to be part of establishing the framework for standards and for balancing the trade-offs between technical standards and perception of services or different values regarding what services are more important." The Director of the Neighborhood Planning Office in Seattle characterizes her task, as "figuring out how we make people shift from being fighters against city hall to having lots of different people with lots of different perspectives getting together to solve problems" (September 16, 1997).

\section{Partnerships}

Another expression of participation and community engagement is the number of partnerships that local governments are involved in both externally and internally. The external partnerships are evident in joint undertakings with school districts, counties, non-profits, community-based 
organizations, neighborhood associations, and private sector organizations. The importance of the partnerships appears to have affected the manager's role significantly. Perkins (July 13, 1997) writes, "[the prevalence of partnerships] requires the city manager to lead by example and foster relationships within the community to help pave the way for those organizational partnerships to be formed."

In Mora's (September 16, 1997) experience, the trend has had a similar impact on staff, especially regarding the partnerships with neighborhood groups. He notes that when hiring department heads, he specifically considers the ability to develop "partnerships, and work with community goals, and elected officials. The partnership element and involvement of neighborhoods and elected officials as well as the connections within and between departments is crucial."

Having been a city manager and now serving as executive director of a civic group of business leaders in Kansas City, Missouri, Jewel Scott (July 25, 1997) observes that there has been a significant shift towards community involvement and ownership of programs and service delivery.

If I were a manager today, I would focus on finding ways to work creatively with the not-for-profit community to provide services and to evaluate and design service delivery systems. Also, I would be more open to building community ownership of issues 
and projects and to seeking the assistance of others in the community to do so. Finally, I would think very differently about what is important to a community's well being. I would work harder to move decisions out into the community.

This discussion of community building and facilitative leadership points the profession of city management in a particular direction--away from professional elitism and towards a community paradigm. It appears that local government administrators must be able to move in this direction if they are to maintain their effectiveness and influence. There is a tacit understanding here that council-manager government itself no longer provides a comfortable, protective cover for the city manager's legitimacy.

\section{Form of Government and The Added Value of City Managers}

Frederickson (1996) has shown how adaptations to both councilmanager and strong mayor forms of government have moderated the distinctions between the two. It is hard to imagine that to the average citizen the remaining differences really do make a difference. Whether they are important remains a point of contention among city management professionals. Tom Downs (November 24, 1997), former Chairman of AMTRAK and a former city manager, argues that they do.

He observes, "The institutions we create are more important [than he formerly thought], enduring, and effective over the long term." He suggests 
that the collapse of local government in the nation's capitol should teach us something about unfulfilled faith in charismatic leadership. Also, it should reinforce our belief that there is long-term value in governmental institutions that sustain and protect continuity, stability, expertise, and the value of public service--like those fostered by council-manager government.

In contrast, Mora (December 5, 1997) observes that council-manager government, in its traditional definition is not always the best or most appropriate for a community. He writes, "Our emphasis as professionals must be on providing expert local government management, regardless of the form of government. This 'ideal' of service can and should be a core value of the profession without dependence on the form of government." Ruder (August 12, 1997), who formerly worked in Phoenix and Billings, both council-manager cities and now works in Seattle, a strong mayor city, adds: "Distinctions about form of government seem much less critical to me than whether people are engaged as problem solvers in their own neighborhoods." Anderson (August 26, 1997) suggests that the success of councilmanager government in eliminating corruption has actually diminished its contemporary attractiveness. Its success has eliminated its original raison d'être. While the reform story is diminishing in attractiveness, strong mayor cities have come to rely more on professionally trained staff and accepted business practices, thus increasing their administrative effectiveness step by step. 
As a corollary, Anderson observes, "Mayors have somehow emerged in this decade as the political 'reformers,' with mayors in Indianapolis, Philadelphia, New York, Chicago, and Los Angeles getting excellent press and praise as the standard bearers for progressive municipal government." Jan Perkins (July 13, 1997) concurs by suggesting that the perceived responsiveness of high profile mayors easily leads to the notion that "we" [professional managers and advocates of council manager government] may be seen as the institution that needs reforming.

The popularity of the charismatic mayor elicited many comments from participants in this research. In many ways the discussion about form of government and concern over the present emergence of the strong mayor as a "reformer" is crucial to the meaning of local government professionalism. It calls into question the value city managers add to municipal government, and thus aims at the heart of professional legitimacy.

For years, the value of city managers has been embedded in the form of government itself. Council manager government without a city manager is inconceivable, by definition. And as long as the form of government retained its prominence as "good government," the value and credibility of the city manager was, in large measure, unquestioned. Robert O'Neill, Jr. (October 29, 1997), County Executive in Fairfax County, Virginia, observes that among the greatest changes in the relationship between elected and appointed officials is the increasing skepticism that elected officials have 
regarding the value of senior management. As the contemporary reform story unfolds with the "mayor taking on the bureaucracy," council-manager government becomes an old story, and the value of the city manager is exposed. This calls for a new definition of the local government professional's roles, responsibilities, and values. Norm King (December 10, 1997) says it best: "The primary issue is not the council-manager plan. The issue is better articulating the added value of professional management. And in doing so, we must distinguish a well run city from a poorly run city in a way which is understood by the citizenry [emphasis added]."

In sum, as prominent mayors become seen as the new reformers, council-manager government becomes an old story. The search for legitimacy is really a search for identifying what value the city manager adds to a community. This is where the community building, facilitative leadership paradigm holds promise.

\section{Process Oriented Management}

Some of the changes identified by the local government administrators in this research focused on managing their internal, organizational role. Technological, demographic, and market-based pressures on governing institutions bring about the changes (Klingner and Nalbandian, 1998, Chs. 1 and 8). Technological advances are noteworthy for two reasons--the amount of knowledge that is generated and the rapidity of change. Increasing 
knowledge often requires occupational specialization. More specialization means that teamwork is even more necessary to link diverse specialists. Interdepartmental differences in perspective are greater than in the past and are articulated more clearly and forcefully by better educated, technically trained staff. The rapidity of technological change suggests that the occupational specializations themselves can become obsolete more quickly than in previous generations. This means that many teams have to exist as temporary organizational fixtures, and employees must become accustomed to working in more than one setting.

Demographic changes are reflected both in the diversity of people who constitute the workforce and in the tremendous demands for flexible work arrangements to accommodate family needs of today's single parents and dual income families. The challenge of workforce diversity manifests itself in different expectations that employees have of one another. In addition, men and women often approach problem solving and managing people differently. And, accommodations to family needs include newer benefits like child care, long-term care, and elder care; and in work arrangements like flex-time, flexplace, job sharing, and a greater desire for part-time, yet permanent work.

George Caravalho (October 20, 1997), City Manager in Santa Clarita, California, says, "The most significant change that has occurred in our profession is the impact that women have had in the workplace. Women seem less concerned with hierarchy and structure, tending to be more 
facilitative in their style. They look for areas of commonality; and they often have a calming approach to problem solving and conflict." Sandra TrippJones (December 30, 1997), City Administrator in Santa Barbara, California, adds, "Women have provided more behaviors not stereotypically male, so that both men and women have more freedom to use styles and skills that suit them individually. Among firefighters, for example, women have added and made it acceptable for men also to demonstrate compassion, empathy and sensitivity to people in traumatic situations. In addition, the offices of women managers often seem safe places for others to talk/vent/try out ideas in a less competitive setting."

And last, competitiveness in the market place puts a premium on responsiveness, quality, and speed. As David Watkins (December 10, 1997) says, "I understand that the role of government does not lend itself entirely to the service model of the private sector, but certain values such as fairness, timeliness, and unified decision making are transferable. Lenexa is moving toward a system where applicants will be viewed in a positive manner and staff will serve as problem solvers."

Gene Denton (June 25, 1997), County Manager in suburban Johnson County, Kansas, indicates the kinds of internal changes that have come about in response to these types of external pressures: 
The structure of government has flattened. We have retrained most of our workers to be more self-reliant and departments to be interdependent. Creativity and innovation have replaced the more sterile values of efficiency and economy. Leadership has leaped ahead of management. Coaches have replaced supervisors. Connectedness, communication, and cooperation have outclassed competition. Quality is more valued than speed. The respected leader is one who is more concerned about how workers are progressing and what they should be, rather than what they should do.

The flattening of hierarchy is prudent when seeking rapid response by technically trained staff. City managers today cannot mandate changes because, more than before, they do not command the technical knowledge to fully understand what they are asking for. A city manager cannot tell a public works director that the council favors a proposed development that requires hooking up to a particular sewer line because it is more economical for the applicant, when the pubic works director says the downstream capacity won't handle the added load of wastewater. In addition, as city staff begin to incorporate facilitative management practices into their own work, city managers who exercise hierarchical control over them put at risk the often fragile agreements staff has negotiated among contending parties. For 
example, on a controversial development project involving landowners, regulatory bodies, financial institutions, and neighbors, planning staff may have negotiated an agreement that incorporates provisions regarding annexation, payment for infrastructure, and land-use. City managers who would exercise hierarchical control over planning staff could jeopardize this agreement. Professional norms and the confidence that come with the mastery of technical knowledge and process skills permit and sometimes encourage technical workers to question hierarchy. Because managers cannot dictate to staff, Denton's statement about being concerned with what workers should be rather than what they should do seems on target.

As managers are forced to reduce reliance on hierarchy, the personal attributes of workers become more crucial to performance, as Denton observes. In fact, in the personnel field, it is not uncommon in the private sector to incorporate "personal attributes" into discussions about merit and competence (Borman and Motowidlo, 1993). This flies in the face of traditional personnel practices where personal attributes are excluded from considerations of knowledge, skills, and abilities.

King's (September 16, 1997) comments capture the overarching thrust of the city manager's administrative role when he says, "I think the most important responsibility of any manager is to manage the values of the organization and to instill a sense of responsibility in employees for them ." This is exactly what David Mora was referring to when he commented that 
the values of staff were crucial to him in his dealings with a diverse council, thus the hiring process must attend to more than just technical competence.

Furthermore, King says that while the vast majority of a city's work can be handled through traditional departments, the most important problems fall outside of traditional departmental boundaries. Hierarchy is of little use in handling these problems that require "independence, creativity and innovation, connectedness, communication, and cooperation," in Denton's words. This is precisely what Donald Schon predicted in 1974 when he wrote Beyond the Stable State and suggested that amidst continual change, values provide stability.

Complicating internal, administrative transitions, according to several managers, is the increasing tendency of councils to become involved in the "how to" rather than the "what" part of governance. Svara's $(1985,1998)$ work shows how the politics/administration dichotomy is more fruitfully viewed in terms of relative involvement of the city manager and city council members in the city's mission, policy, administration, and management functions. Using his terminology, elected officials have become more involved in administration and management, according to the participants in this research.

Buchanan (October 17, 1997) sums up the involvement of elected officials in this way: 
In an evaluation not too long ago, one of the Commissioners suggested that she would be more comfortable if I brought to her the projects as I was working on them rather than when they were completed. She used the analogy of a baby. She said she was part of the family and she wanted to see the baby. She wanted not only to see the clean baby with a shiny ribbon in her hair, but she wanted to see the baby, messy diaper and all.

Commenting on Buchanan's metaphor, Sandra Tripp-Jones (December 30, 1997) writes:

They [the governing body] like being able to 'dress the baby,' to plan how to promote the idea. I need to be comfortable brainstorming with them as opposed to 'providing the best and only answer.' This is a change from even five years ago. Like the facilitation skills needed to foster more public participation without controlling it, the professional manager needs the selfconfidence to brainstorm with council and be wrong, and to not need to have all the answers. This also means developing staff who can do the same.

The increasing interest elected officials show in "how to" is understandable if one recognizes that how decisions are reached conveys as 
much about representation, individual rights, and equity--essential values in community building-as the substance of the decision itself. If professional staff fails to acknowledge this council interest, it distances itself from the council and plants the seeds of council skepticism and distrust.

\section{Discussion and Conclusions}

Several years ago I described the changes that had occurred in the meaning of professionalism in local government as three transformations in roles, responsibilities, and values of city managers. I conclude by returning to those three transformations, relating them to the primary conclusions in this present research.

As long as the council-manager plan symbolized reform government, the city manager's roles, responsibilities, and values were protected--even if they were not easily articulated or understood. The legitimacy of the city manager rested in the form of government and the story it promised--nonpolitical, efficient and responsive government. But as the memory of patronage and widespread corruption has faded, the most persuasive rationale for council-manager government is lost, not only for citizens but for governing body members themselves. In this environment, city managers are vulnerable to elected officials and citizens skeptical of the expertise of any government employee, even questioning the value of government itself. 
Burdened with maintaining their legitimacy, some managers seek from their peers and ICMA a renewed and vigorous defense of councilmanager government. My impression is that the value of professionalism in local government must be established independent of government form, and I think the comments of several managers in this study point in that direction. In searching for the connection between political leadership and administrative capacity, the concepts of community building and facilitative leadership are recurring themes. These themes provide clues to the present and future roles, responsibilities, and values of city managers as models for local government professionals in general.

\section{Roles}

Many aspects of the manager's job remain the same; keeping the council informed, providing continuity and stability, telling the council what it does not necessarily want to hear, and balancing short run interests against a long-run, "greater good" perspective. The difference between now and 10 years ago is in the emphasis on the facilitative role of the manager. Some 20 years ago, the International City Management Association's Future Horizons Committee (Rutter, 1980, p. 2) characterized its dialogue with the sentence: "Welcome, I am Jennifer Stene, the city coordinator." After examining the comments I received for this study, it appears that the future is now! Frederickson's (1997B, Ch. 3) review of literature on governance includes numerous references to academic studies emphasizing partnerships, 
networking, coordinating, and connecting as the essence of the "new public management."

Throughout the discussion of building community, the internal and external facilitative roles of the manager have been emphasized. These roles grow from the emphasis on partnerships, responsiveness and customer service, quality management, and coordinating divergent departmental perspectives. In short, "how" a city government conducts its business, whether with its own employees or with the governing body or citizens, has become as important as "what" is done.

In this environment, supporting the council's work--a longstanding role expectation of the chief administrative officer and staff--requires a facilitative orientation as part of the definition of professionalism in local government. There is a growing understanding that facilitative work is not designed to "make people feel better." It is designed to help promote a problem solving orientation and develop consensus among diverse interests. Eric Anderson (September 17, 1997) says, "This is not warm and fuzzy stuff; it is hard work. I have found it to be the toughest work we do. You've got to be incredibly patient and thick-skinned, and you have to have some sense that there truly is value in these processes because they are tremendously time consuming and occasionally abusive."

The connection he makes between facilitative staff work, support for the governing body, and building governance capacity and credibility, places 
the facilitative role into a more important theoretical perspective than local government professionals commonly understand. Developing facilitative staff work requires more than just skill building. It takes us back to the values argument that King and Mora made earlier. Managing the values of the organization means connecting the overarching organizational sense of what is good/right with the work of the governing body and the community.

\section{Responsibilities}

The second tenet discussed in 1991 asserted that managers were responsive to their governing body but responsible to values expressed in the community more broadly. That responsibility is given more form when linked to community building.

The partnership between staff and governing body achieved through facilitative leadership is targeted towards community building. The concept of community building, as elusive as it might be to define, nevertheless provides more guidance than the vague, simplistic counsel that staff and the governing body are partners in governance with the governing body establishing priorities and staff carrying out policy. The community building concept provides a legitimate anchor because it establishes a concrete purpose of government that citizens can readily understand and endorse. It is not the only one; but it can provide a fruitful point of departure for real governing bodies and real managers seeking an effective relationship and way to engage citizens. It provides a way to make democracy work. 
The responsibility of the city manager is to empower the governing body and citizens by helping to develop and use the tools of engagement. This is where the facilitative leadership roles enter--framing issues and processes to deal with diverse interests, to focus on interests rather than positions when problem solving, and to develop collaborative partnerships in policymaking and service delivery.

\section{Values}

As a third tenet, in 1991, I argued that representation, individual rights, and social equity combined with efficiency to form a value base for professionalism in city management. The concept of community building organizes those values. It suggests that building a sense of community requires a foundation of rights, fairness, and representation along with evidence that collectively a community can accomplish some tasks more efficiently and effectively than its members could do on their own--streets, sewers, stormwater management, land-use planning, and so on. Giving up some freedom on behalf of the collective good is made more palatable when rights, equity, and representation of interests are guaranteed (Tussman, 1960).

In addition to providing a connection among these values, the community building concept can help us see the future of facilitative leadership within an internal organizational community as well as within external political communities. Increasing levels of diversity within 
organizations place a premium on facilitative leadership aimed at building commitment to collective organizational purposes. The same can be said when collegiality and teamwork replace hierarchy.

In asserting that the contemporary meaning of professionalism incorporate facilitative leadership and community building, I have chosen to downplay "the enduring commitment to public service" (Frederickson, 1997B) as a central feature. I do not doubt this sense of obligation to the public good as a defining element for those who choose to become city managers. I have serious reservations, however, whether those outside of academic and professional circles find that commitment believable enough to grant city managers legitimacy. Those who come to our governing institutions seeking satisfaction of their private interests always find ways to mask those interests as the public good. We have become so facile at manipulating data to suit these hollow portrayals that claims of advancing, nurturing, or living by the public interest have become suspect by dispassionate citizens and governing body members alike. Brint (1994) has shown that professional status is more likely to be conferred upon those who can demonstrate skills employed in ways the rest of us--average citizens--value rather than in the virtue of self-proclaimed motives. That is why skill in community building rather than a calling to public service is more persuasive to me as an anchor for contemporary professionalism. 
Finally, the success at postulating facilitative leadership and community building as the anchors for contemporary professionalism in local government will depend upon two factors. The first is whether city mangers are willing to acknowledge that the value they add to governing processes can be found in facilitative leadership and community building rather than associated principally in the issue of form of government. A second, and more challenging task, is whether the profession can formulate these two concepts into a "new story" that will connect and build on the reform heritage in a way that appeals to citizens.

\section{References}

Anderson, Eric (August 26, 1997). Correspondence with John Nalbandian. (September 17, 1997). Panel discussion at ICMA conference in Vancouver, British Columbia.

Bledsoe, Timothy (1993). Careers in City Politics: The Case for Urban Democracy. Pittsburgh: University of Pittsburgh Press.

Borman, W. C., and S. J. Motowidlo (1993). "Expanding the Criterion Domain to Include Elements of Contextual Performance." In F. L. Schmitt, W. C. Borman, and Associates, eds. Personnel Selection in Organizations. San Francisco: Jossey Bass,

Box, Richard C. (1998). Citizen Governance: Leading American Communities into the $21^{\text {st }}$ Century. Thousand Oaks, CA: Sage.

Brint, Steven (1994). In an Age of Experts. Princeton, NJ: Princeton University Press.

Buchanan, William (October 17, 1997). Correspondence with John Nalbandian.

Caravalho, George (October 20, 1997). Correspondence with John Nalbandian.

Church, Charles (November 27, 1997). Correspondence with John Nalbandian.

Denton, Eugene (June 25, 1997). Correspondence with John Nalbandian.

Downs, Thomas (November 24, 1997). Correspondence with John Nalbandian. 
Etzioni, Amitai, ed. (1995). New Communitarian Thinking. Charlottesville: University Press of Virginia.

Fowler, Robert Booth (1991). A Dance with Community: The Contemporary Debate in American Political Thought. Lawrence, KS: University Press of Kansas.

Frederickson, H. George (December 1997A). "Facing the Community." Kettering Review, 28-37. , ed. (1989). Ideal and Practice in Council-Manager Government. Washington, DC: International City Management Association (1997B). The Spirit of Public Administration. San Francisco: Jossey Bass.

(1996). "Type III Cities." Unpublished manuscript. Department of Public Administration, University of Kansas.

Gardner, Howard (1995). Leading Minds. New York: Basic Books.

Glendon, M. A. (1991). Rights Talk: The Impoverishment of Political Discourse. New York: Free Press.

King, Norm (December 10, 1997). Correspondence with John Nalbandian. (September 16, 1997). Panel discussion at ICMA conference in Vancouver, British Columbia.

Klingner, Donald E., and John Nalbandian (1998). Public Personnel Management: Contexts and Strategies, $4^{\text {th }}$ ed. Chs. 1 and 8. Upper Saddle River, NJ: Prentice Hall.

Lappe, Frances Moore, and Paul Martin DuBois (1994). The Quickening of America: Rebuilding our Nation, Remaking Our Lives. San Francisco: Jossey Bass.

Mahtesian, Charles (1997). "The Politics of Ugliness." Governing Magazine 10:18-22.

Mathews, David (1994). Politics for People: Finding a Responsible Public Voice. Urbana, IL: University of Chicago Press.

Mora, David (December 5, 1997). Correspondence with John Nalbandian. (September 16, 1997). Panel discussion at ICMA conference in Vancouver, British Columbia.

Nalbandian, John (1989). "The Contemporary Role of City Managers." American Review of Public Administration 19:261-278. (1991). Professionalism in Local Government: Roles, Responsibilities, and Values of City Managers. San Francisco: Jossey Bass.

(1990). "Tenets of Contemporary Professionalism in Local Government." Public Administration Review 50:654-663.

O'Neill, Robert, Jr. (October 29, 1997). Correspondence with John Nalbandian.

Perkins, Jan (July 13, 1997). Correspondence with John Nalbandian. (July 21, 1997). Correspondence with John Nalbandian. 
Putnam, Robert D. (1993). Making Democracy Work: Civic Traditions in Modern Italy. Princeton, NJ: Princeton University Press.

Rice, Tom W., and Alexander F. Sumberg (1997). "Civic Culture and Government Performance in the American States." Publius 27:99-114.

Ruder, Karma (August 12, 1997). Correspondence with John Nalbandian. (December 15, 1997). Correspondence with John Nalbandian. (September 16, 1997). Panel discussion at ICMA conference in Vancouver, British Columbia.

Rutter, Lawrence. (1980). The Essential Community. Washington, DC: International City Management Association.

Schon, Donald (1974). Beyond the Stable State. New York: Norton. Scott, Jewel (July 25, 1997). Correspondence with John Nalbandian. Selznick, Philip (1992). The Moral Commonwealth: Social Theory and the Promise of Community. Berkeley, CA: University of California Press.

Stillman, II., R. J. (1974). The Rise of the City Manager. Albuquerque: University of New Mexico Press.

Svara, James H. (1985). "Dichotomy and Duality: Reconceptualizing the Relationship Between Politics and Administration in Council-Manager Cities." Public Administration Review 45:221-232. (1998). "The Politics-Administration Dichotomy Model as Aberration." Public Administration Review 58:51-58.

Thomas, John C. (1986). Between Citizen and City. Lawrence, KS: University Press of Kansas.

Tripp-Jones, Sandra (December 30, 1997). Correspondence with John Nalbandian.

Tussman, Joseph (1960). Obligation and the Body Politic. New York: Oxford University Press.

Watkins, David (July 13, 1997). Correspondence with John Nalbandian. (December 10, 1997). Correspondence with John Nalbandian. 